\title{
EL CARIBE COLOMBIANO EN IMÁGENES: EXPEDICIONES EXTRANJERAS EN TORNO AL TERREMOTO EN PANAMÁ A FINALES DEL SIGLO XIX
}

The Colombian Caribbean in images: foreign expeditions around the earthquake in Panama at the end of the 19th century.

\author{
Leguis Antonio Gómez Castaño \\ Universidad de La Laguna, Tenerife, España
}

saudade1971@protonmail.com

Recibido: 24-01-2021

Aprobado: 15-03-2021

Leguis Antonio Gómez Castaño es doctor en Historia de la Universidad de La Laguna en Tenerife, España. Ha publicado, entre otros, los siguientes artículos: Las miradas del viajero: la historiografía de la otredad en Canarias y el Caribe Colombiano y El colegio Universidad del estado soberano de Bolívar 1870 - 1885.

\section{RESUMEN}

En 1882 la región de Panamá sufrió el que es tal vez el peor evento sísmico de su historia. Junto con la construcción del gran canal que se estaba construyendo, el terremoto despertó el interés de científicos extranjeros quienes viajaron al Caribe Colombiano a visitar la región. Como consecuencia de dichas visitas llevadas a cabo entre 1882 y 1886, se produjo un archivo fotográfico que este trabajo intenta rescatar.

Palabras clave: Caribe colombiano, Panamá, siglo XIX, eventos sísmicos, fotografías.

\section{ABSTRACT}

In 1882 the Panama region suffers one of the most devastating seismic events in its history. Alongside with the construction of the big channel, the earthquake sparked academic and scientific interest of foreigners who traveled to the Colombian Caribbean to pay their visit. As a result of those visits carried out between 1882 and 1886, a photographic archive was produced and this article tries to rescue.

Keywords: Colombian Caribbean, Panama, 19th century, seismic events, photographs. 


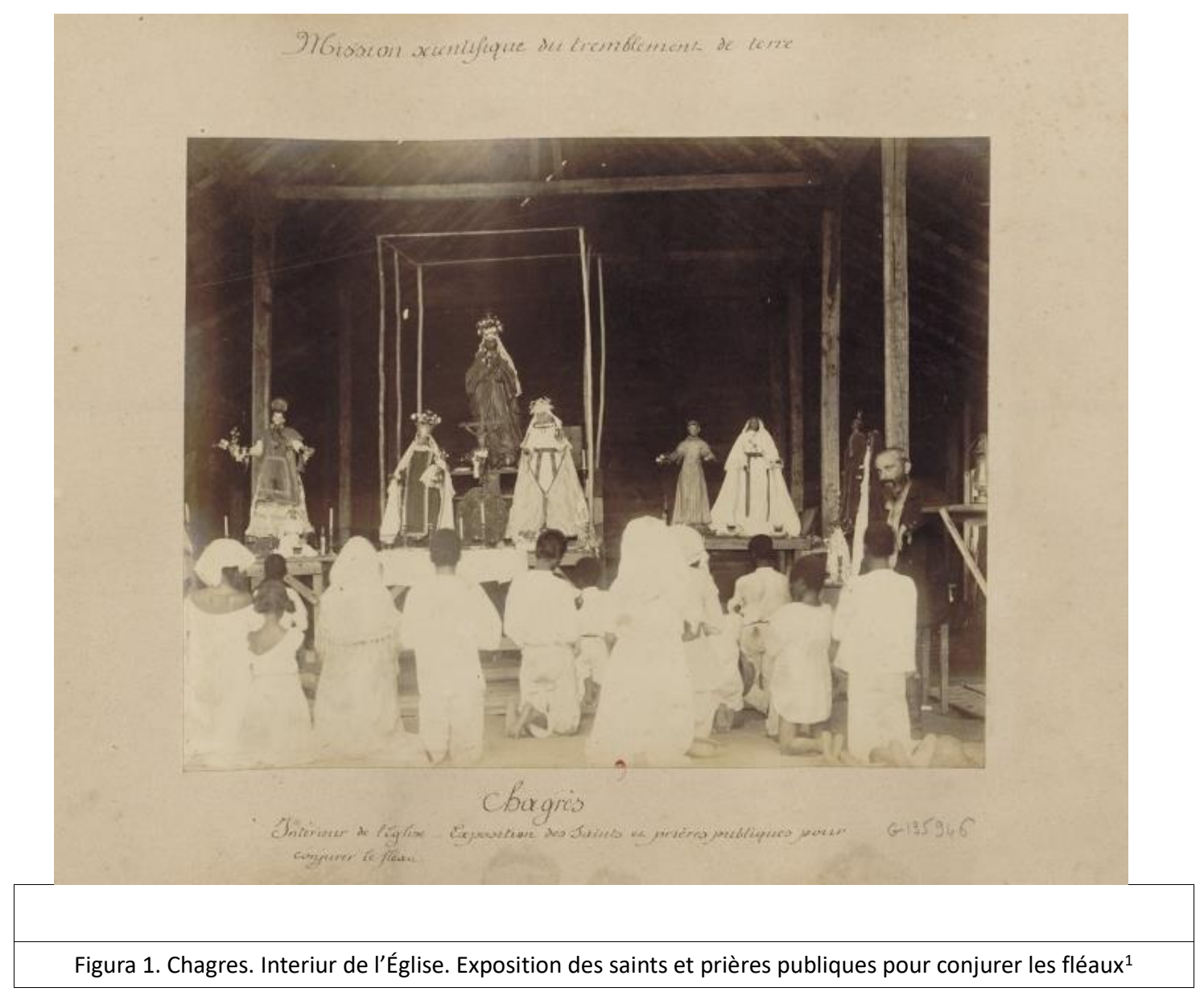

Es de día, y aunque la percepción inicial de la profundidad del espacio abarcado por la imagen parece sugerir que es de noche, la realidad es que los participantes se encuentran a plena luz del día, llevando a cabo, -tal y como lo expresa la leyenda consignada en la parte inferior de la fotografía-, un ceremonial católico que intenta frenar, en el sitio donde se celebra, y quizás en todo el país², la reproducción de un evento que acaba de sacudir las entrañas mismas del Panamá de finales del siglo XIX.

1 Interior de la iglesia. Exposición de santos y plegarias públicas para conjurar las calamidades. Nota: Esta y las demás traducciones son del autor.

2 La Real Academia de la Lengua Española tiene varias definiciones del término país, pero entre ellas aquí se hace referencia a aquella que establece país como un territorio con características geográficas y culturales propias, que puede constituir una entidad política dentro de un estado. https://dle.rae.es/pa\%C3\%Ads 
Revista Herencia, Vol. 34 (2), enero-junio, 2021.

No queda clara la fecha exacta del ritual, pero sí se puede apreciar a un grupo de jóvenes mulatos, arrodillados y vestidos todos de un blanco que resalta no solo frente a la aparente oscuridad del espacio, sino también frente a sus propias pieles. De frente a ellos, seis representaciones de la imaginería religiosa católica, aparecen levantadas sobre mesas rusticas con el fin de mostrar que han sobrevivido a la sacudida, como el milagro que se espera. Entre las estatuas a las que se le rinde un culto que agrede las rodillas de los jóvenes devotos, quienes son vigilados por aquel que parece ser el cura del pueblo, está la que probablemente sea la figura de la virgen Santa María la Antigua, la patrona de la región de Chagres y de toda Panamá, ensalzada por encima de los otros santos y vírgenes de la exposición en lo que aparenta aspirar a ser un palio (véase figura 1).

La celebración de un ceremonial litúrgico en medio del campo, como parece indicar la arquitectura humilde del templo en el que se lleva a cabo el acto devocional, no debería tener mayor trascendencia, a menos que la actividad revista una significación especial, como es el caso que acompaña esta demostración de fe religiosa, atendiendo a los acontecimientos que lo precedieron. En la madrugada del 7 de septiembre de 1882, un terremoto de magnitudes nunca antes vistas sacudía gran parte del territorio de Panamá.

A una distancia superior a treinta kilómetros de la zona de Chagres, Wolfred Nelson, un médico residente, quien viajó como corresponsal del periódico canadiense La Gazette a ciudad de Panamá, se despertó pensando que durante el sueño alguien había agitado su cama, a tal punto que lo había hecho despertar. Debido a que aún no llegaba el alba por ser todavía muy temprano, Nelson no pudo notar nada, tal vez porque se encontraba aturdido; lo evidencia el hecho de recordar haberse sentado en su cama durante un instante para tratar de poner sus ideas en orden. Sin lograrlo, decidió ponerse de pie y caminar hacia el balcón de la habitación donde se alojaba, y fue cuando cayó en cuenta de la realidad que lo llevó a abrir los ojos tan repentinamente aquella madrugada. Panamá había sufrido un potente temblor que sacudió no solo los cimientos del universo creado en sus sueños, sino también las bases del hotel donde Nelson se hospedaba y, de paso, la ciudad entera:

While standing on that balcony trying to account for the cause that had awakened me, the whole building trembled violently, and there was a groaning, crunching noise that I never shall forget. 
Revista Herencia, Vol. 34 (2), enero-junio, 2021.

(...) As soon as the terrible vibration began I stepped over the railing of the balcony and down on the railing of the balcony of the adjoining house, then jumped to the floor, and ran its full length as rapidly as I could. On getting to the end there was a house some ten feet below me. The only idea I had at the time was that I did not like to die like a rat crushed in a cage. Having had no experience with earthquakes within the tropics, I didn't then realize that it was one. Following the violent shake, all was quiet $(. . .)^{3}$

Tener que vivir semejante situación, debió ser lo más vibrante que el aprendiz de médico y corresponsal alguna vez experimentó en su vida, al punto de que varios años después, cuando rememoró lo sucedido en el relato de su estancia, cada palabra parecía reconstruir la imagen guardada en sus recuerdos, como si estuviese con sus palabras reviviendo el temblor:

I went into my room, and as soon as I realized it was an earthquake, I looked at my watch; it was 3:20. My bathtub had been partially filled with water the night before for my morning bath. The oscillation of the building had thrown a part of its contents over the floor, bottles were knocked down, others were broken, and the ceiling and walls were cracked. (...) We dressed as hastily as possible to get out into the open, and when we got down into the hall found the servants gathered there. (...) When we found the Colombian servants they were sadly frightened. It would seem that when the first shock came they opened a front door to rush out into the street, but did not do so as the tiles on the house came down in a perfect shower. Immediately following the shock and before we had walked down to the main plaza, the whole city was alive with exclamations of terror, and the streets were full of excited people, many of whom had candles. ${ }^{4}$

Los acontecimientos que rodean el terremoto en Panamá en el año 1882, se pueden leer

desde varias fuentes, aunque con mayor detenimiento en el relato que hizo Nelson de los

3 Mientras estaba en el balcón tratando de dar cuenta de la causa que me despertó, todo el edificio tembló violentamente y hubo un gemido, un crujido que nunca olvidare. Tan pronto como empezó la terrible vibración, me trepé sobre las barandas del balcón y bajé a las barandas del balcón de la casa contigua, luego salté al piso y corrí a lo largo tan rápido como pude. Llegando al final había una casa unos diez pies debajo de mí. La única idea que tenía al instante era que no quería morir como una rata aplastada en una jaula. Sin haber tenido ninguna experiencia con terremotos dentro del trópico, no me di cuenta de que este era uno. Después de la violenta sacudida, todo se quedó en silencio.... Nelson, Wolfred (1889): Five years at Panama. The trans-isthmian canal. New York: Belford Company Publishers. Página 170.

$4 \quad$ Fui a mi cuarto y tan pronto como me di cuenta de que era un terremoto, miré mi reloj, eran las 3:20. Mi bañera había sido parcialmente llenada con agua la noche anterior para mi baño de la mañana. La oscilación del edificio había lanzado una parte de su contenido sobre el piso, botellas habían sido derribadas, otras estaban rotas y el techo y las paredes estaban rajadas. (...) Nos vestimos tan rápido como pudimos, para salir a lo abierto, y cuando llegamos a la sala baja encontramos a los sirvientes reunidos allí. (...) Cuando encontramos a los sirvientes colombianos, ellos estaban tristemente asustados. Parecería que cuando la primera sacudida vino, ellos abrieron la puerta frontal para salir corriendo a la calle, pero no lo hicieron porque las losas en la casa se vinieron abajo como en cascada. Inmediatamente después de la sacudida y antes de que camináramos hacia la plaza principal, toda la ciudad estaba viva con exclamaciones de terror y las calles estaban llenas de gente exaltada, muchos de los cuales llevaban velas. Nelson, Wolfred (1889): Five years at Panamá...Op cit, Pagina 171. 
Revista Herencia, Vol. 34 (2), enero-junio, 2021.

mismos, además de otras experiencias relacionadas con su prolongada estancia en esa parte del Caribe Colombiano durante un lapso de cinco años. En sus memorias de viaje llamadas Five years at Panamá. The trans-isthmian canal ${ }^{5}$, las cuales aparecieron por primera vez en 1889, y cuya existencia y riqueza narrativa lo hace un texto de obligada referencia para aquellos interesados en el estudio de viajeros por el Gran Caribe de finales del siglo XIX, pero en especial para aquellas personas estudiosas de la historia panameña, Nelson describe gran parte de sus experiencias en la mencionada región, la vida y costumbres de los habitantes y los aspectos económicos, como si hiciera las veces de un etnólogo en pleno proceso de trabajo de campo, -costumbre que repetirán una y otra vez los viajeros en un proceso constante por narrar al otro (Todorov, 1991; Spurr, 2012), y por supuesto, las descripciones sobre los avances y retrocesos en la construcción del gran canal, razón última de su experiencia por fuera de su país de origen.

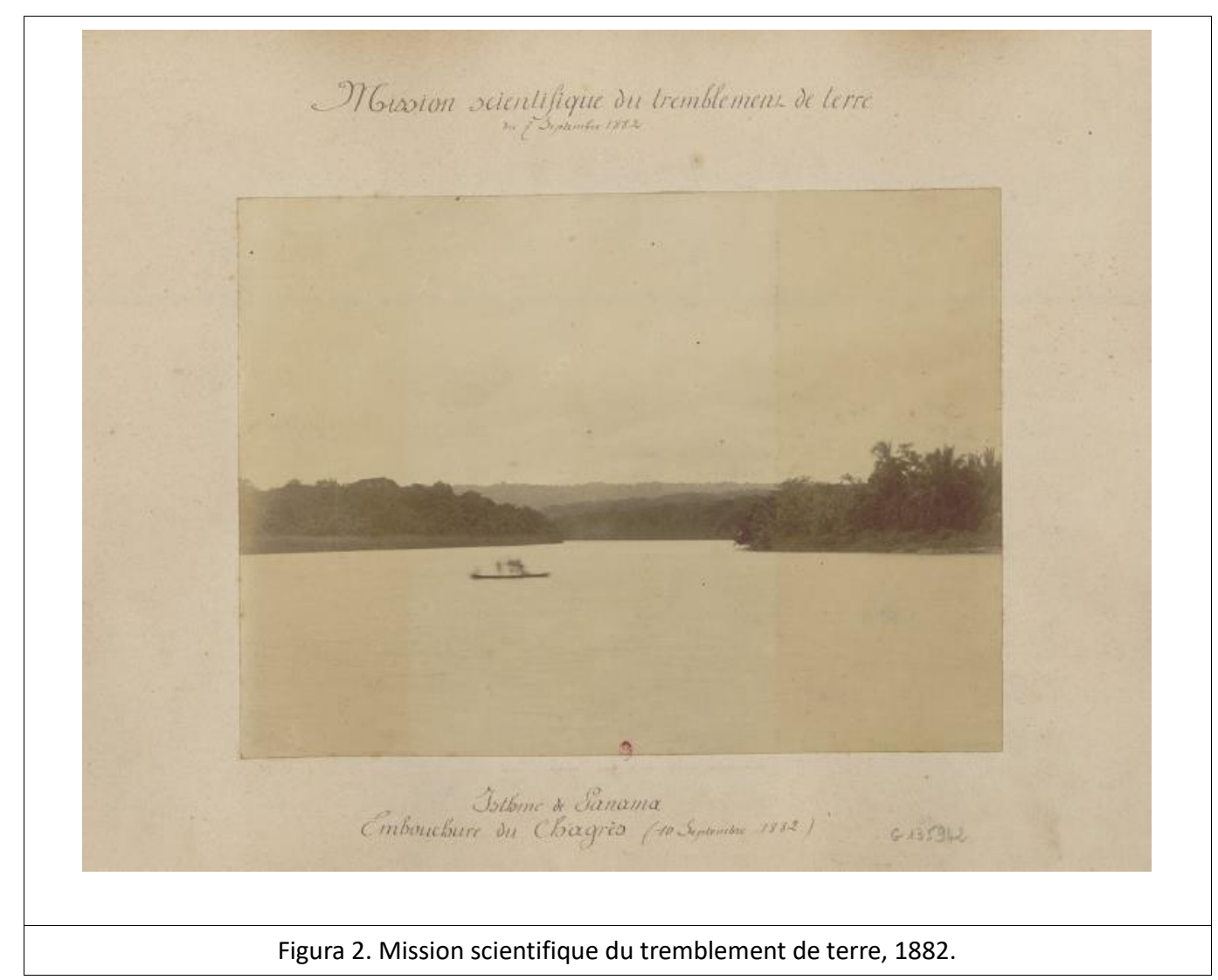

$5 \quad$ Nelson, Wolfred (1889): Five years at Panamá...Op cit 
Menos conocidas son, sin embargo, las imágenes y el interés que dicho evento sísmico provocó entre la comunidad científica internacional. Por ejemplo, comenzando el mismo año del cataclismo, se llevaron a cabo una serie de misiones con carácter exploratorio, algunas de ellas en torno a los sucesos causados por el seísmo de 1882 en distintas partes de Panamá. Al mismo tiempo, también se realizaron otras expediciones en ciudades como Cartagena, Barranquilla, las islas de Guadalupe y Martinica, y algunas zonas de Venezuela. Estas misiones tuvieron varias denominaciones y se hicieron a lo largo de varios años, aunque no queda clara la conexión entre las misiones exploratorias en el Caribe Colombiano y las que se realizaron en otras partes del Gran Caribe.

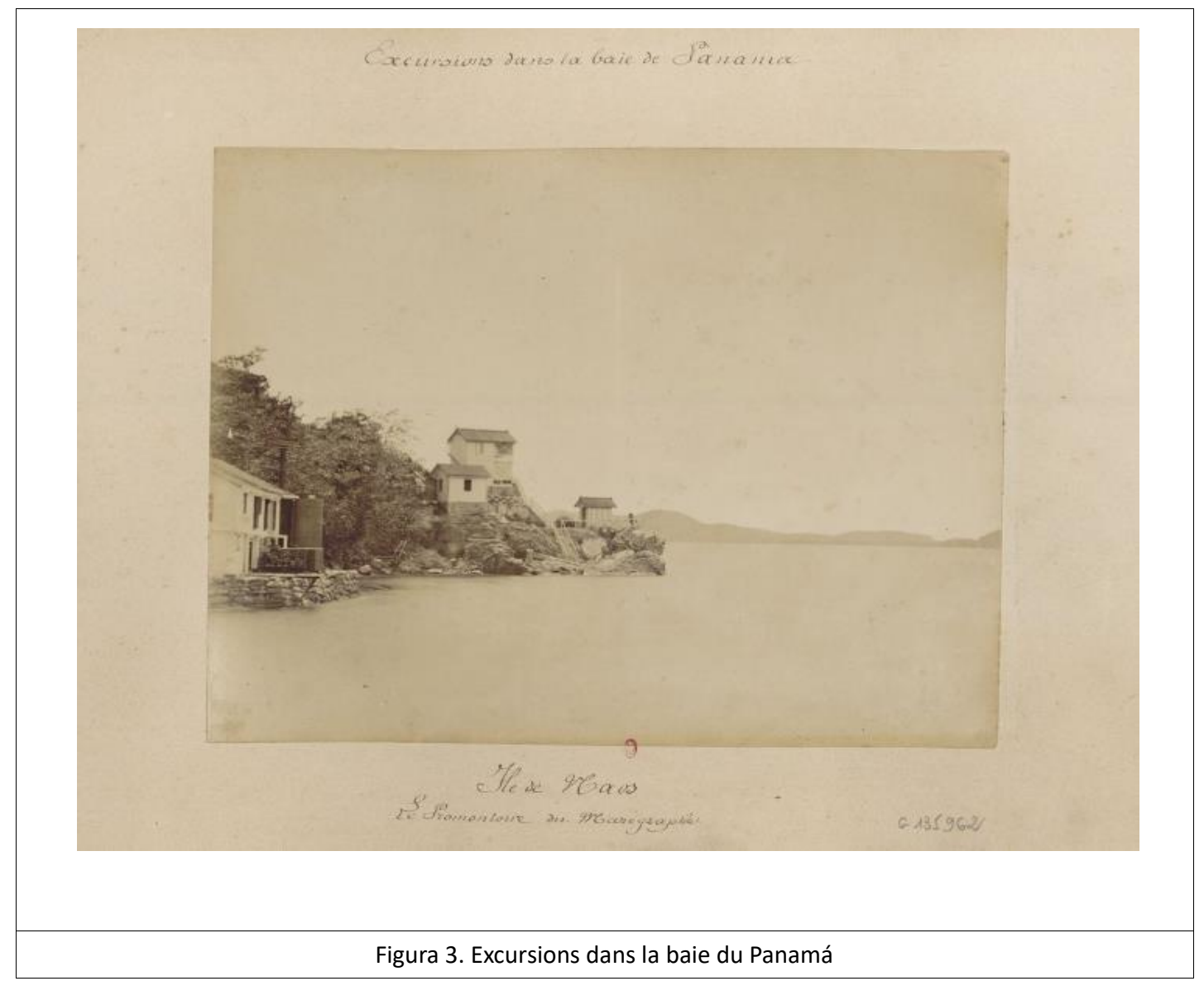

Dado el avance tecnológico de finales del siglo XIX en torno a las imágenes fotográficas, todas estas misiones y excursiones dejaron una huella fotográfica en positivo que 
Revista Herencia, Vol. 34 (2), enero-junio, 2021.

terminaron guardadas en la Biblioteca Nacional de Francia ${ }^{6}$, pero, desafortunadamente, no se conoce la existencia de relatos escritos acerca de dichos eventos expedicionarios, ni sus resultados. Más allá de la publicación de las imágenes, las cuales aparecen compendiadas en un volumen Ilamado Excursions et explorations dans la Colombie, Venezuela, Antilles, Etats-Units, Canadá, Tahiti ${ }^{7}$, no se conocen otros datos relevantes de dichas actividades científicas. Sin embargo, estas imágenes son en sí mismas evidencia más que suficiente de una serie de periplos llevados a cabo en la región y ellas muestran, no solo el interés de aquellos que capturaron los momentos, sino que también ponen de manifiesto unas circunstancias, como en este caso, de varios sitios, de sus habitantes y de las condiciones de vida material de las áreas visitadas. Algunos de los nombres adoptados fueron: Mission scientifique du temblement de terre (1882) (figura 2),

$6 \quad$ En adelante BNF.

7 Guberman, Theodore, De Meuse, Robert et Cannelle (1881-1887): Excursions et explorations dans la Colombie, Venezuela, Antilles, Etats-Units, Canadá, Tahití. Paris: (n/a). La consulta con el personal especializado de la Biblioteca Nacional de Francia (BNF), no arrojó mayores datos en relación con quienes participaron en las misiones y expediciones, más allá de la presencia de un explorador francés de apellido Cannelle, quien además se desempeñaba como ingeniero de la Compañía del Canal de Panamá y cuya fotografía aparece en la portada del archivo digital existente y que está disponible para los interesados en: https://gallica.bnf.fr/ark:/12148/btv1b8447757j. Así mismo, respecto a la autoría de las fotografías, parecen haber sido tomadas por dos fotógrafos que participaron de las misiones, Guberman (1841?-1926), de origen alemán y con residencia en Estados Unidos y De Meuse (18..?-19..?), de origen belga. Del explorador Cannelle, no se ha podido identificar su nombre de pila. 
Revista Herencia, Vol. 34 (2), enero-junio, 2021.

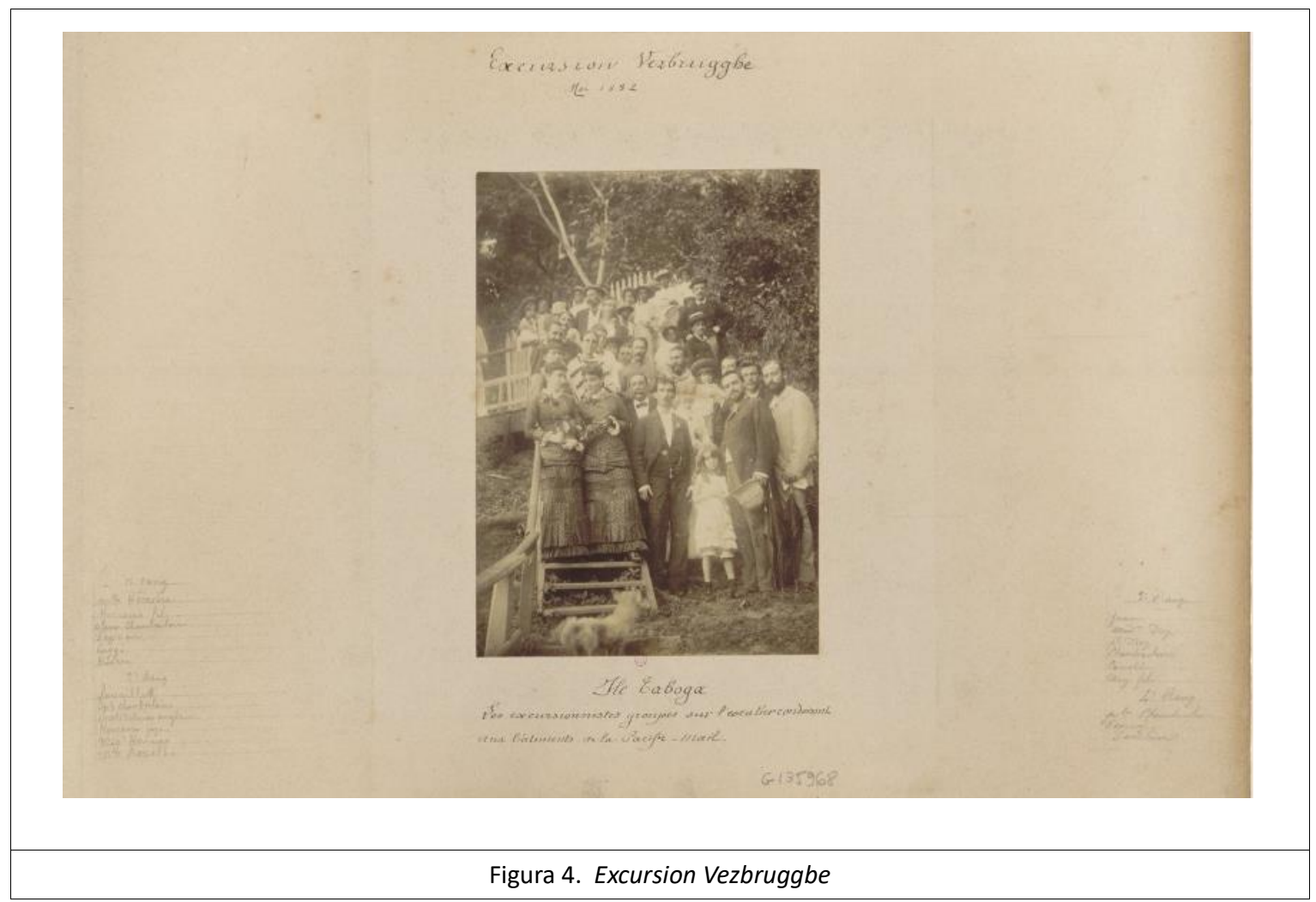

Excursions dans la baie de Panamá (1882) (Figura 3), Excursion Vezbruggbe (1882) (figura 4), Excursion au Rio Venao (1883) (figura 5), 
Revista Herencia, Vol. 34 (2), enero-junio, 2021.

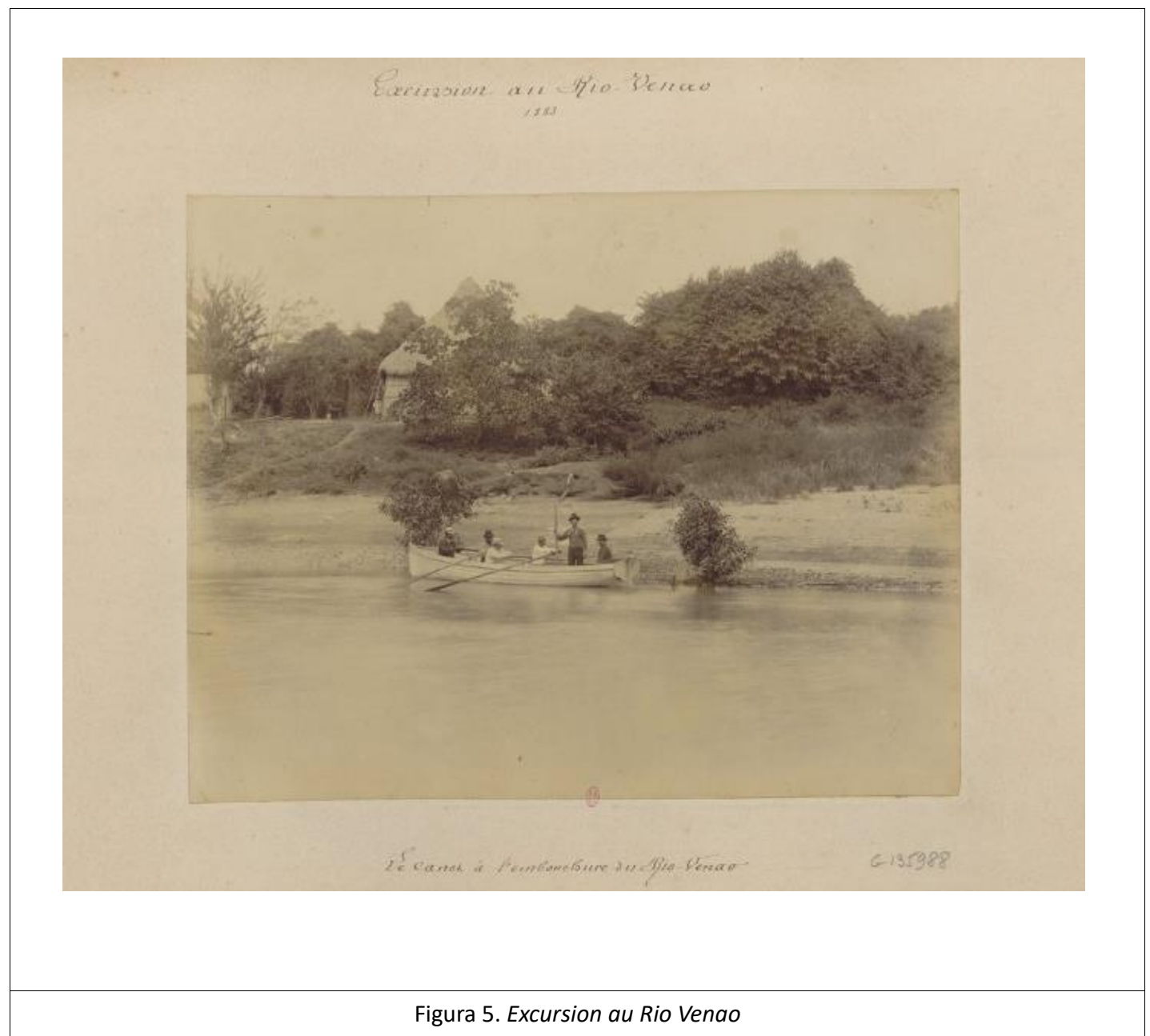

Excursion au Rio Indias (1883) (figura 6), Excursion dans la baie de Limon (1883) (figura 7), Excursion a l'Ile Taboga (1884) (figura 8), Mission du Magdalene (1884) (figura 9), Excursion a la Sardanilla (1885) y Excursion a Rio Bayano (1886). El total de imágenes que dichas excursiones produjeron -al menos las que fueron publicadas-, es de 155 , de las cuales solo 125 están accesibles en la página de la BNF. Por razones de espacio, y porque, además, como es normal con el paso del tiempo, no todas mantienen la calidad que permite verlas con la requerida claridad para ser reproducidas. Por ello, solo se usarán algunas para visualizar los sitios visitados del Caribe Colombiano de finales del siglo XIX. 
Revista Herencia, Vol. 34 (2), enero-junio, 2021.
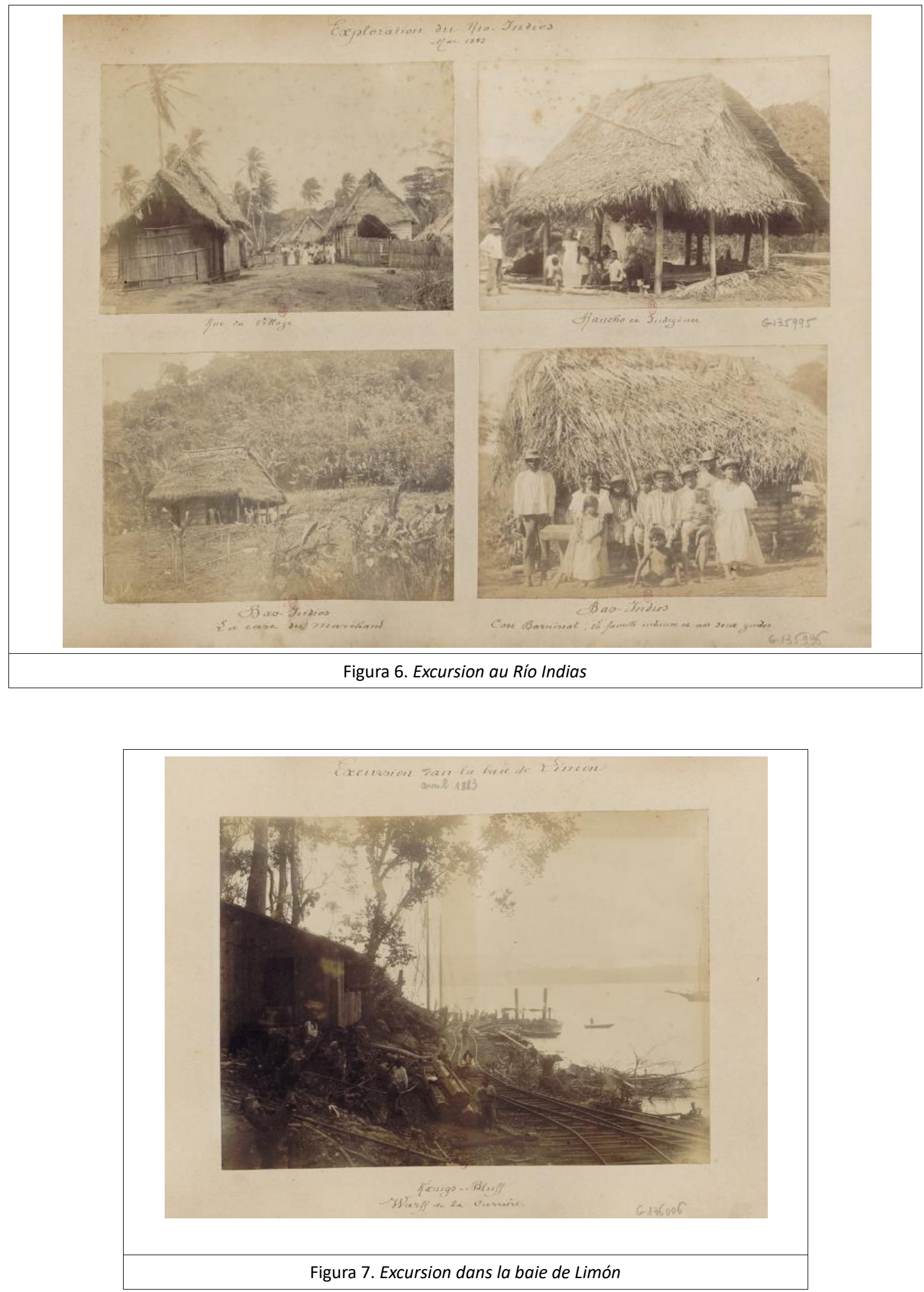
Revista Herencia, Vol. 34 (2), enero-junio, 2021.
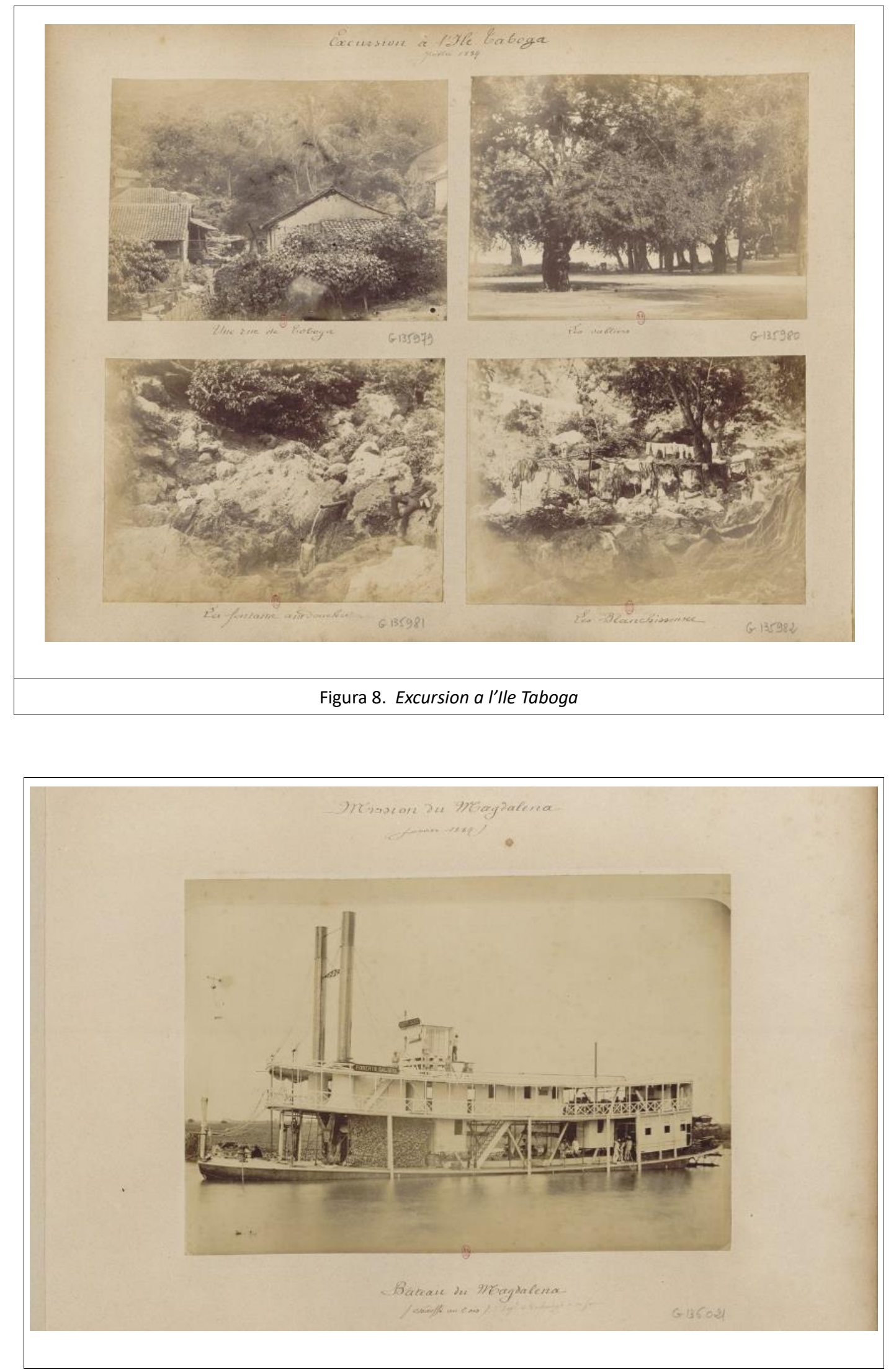
Revista Herencia, Vol. 34 (2), enero-junio, 2021.

Figura 9. Mission du Magdalene
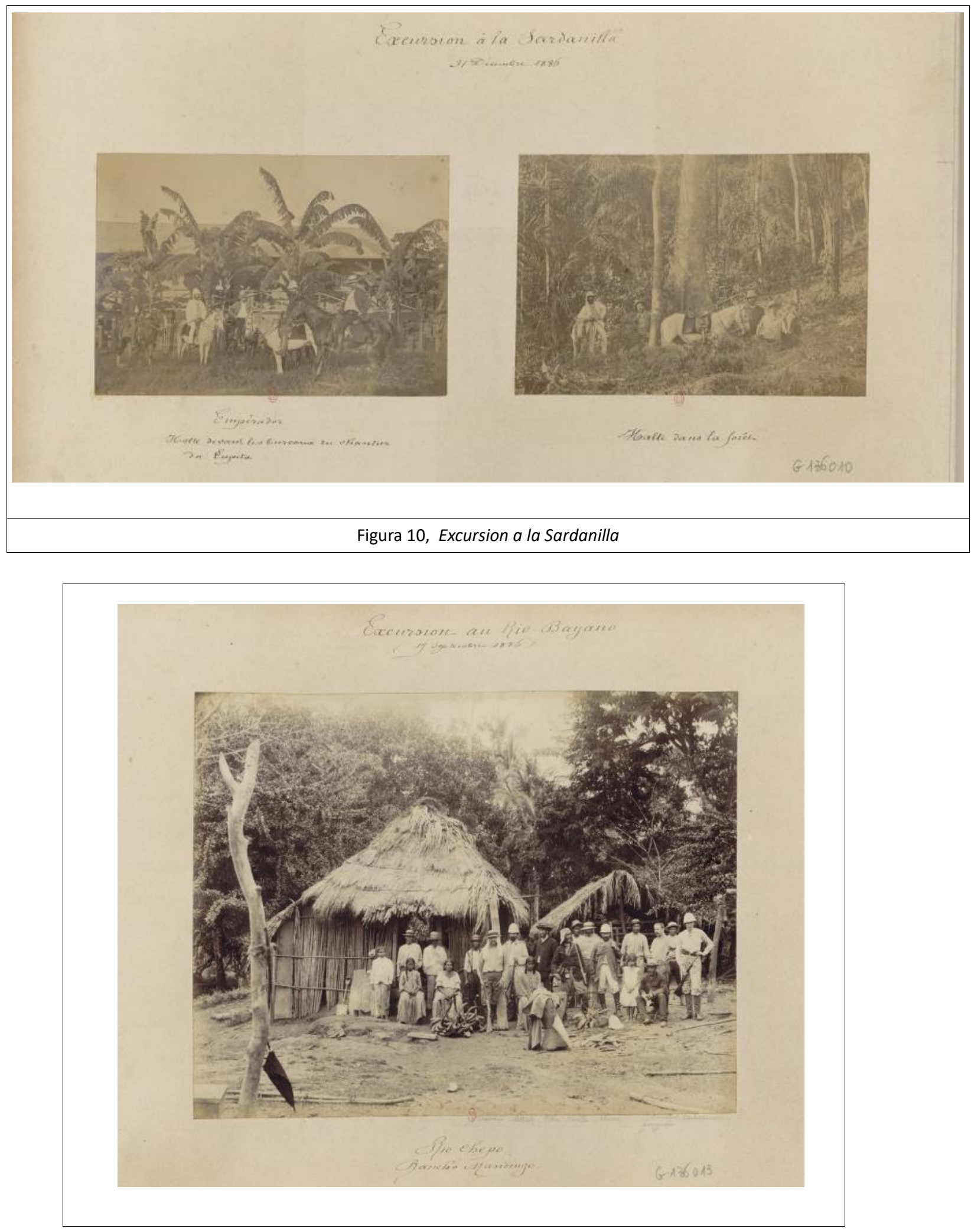
Revista Herencia, Vol. 34 (2), enero-junio, 2021.

Como bien lo ha planteado el historiador Peter Burke en su libro Eyewitnessing ${ }^{8}$, las imágenes han sido un elemento de análisis histórico poco abordado por los historiadores, de ahí que hable de the invisibility of the visual, dando a entender que, a pesar de la presencia del mundo de lo visual a lo largo y ancho de la historia de la humanidad, ha habido una tendencia persistente a dejarlo de lado por preferir los textos y otras fuentes escritas e incluso orales, mientras el uso que se le ha dado a las imágenes ha tenido un carácter de acompañamiento al quehacer historiográfico, en el que no se hace análisis directo de las mismas, desechándolas como evidencias históricas que al fin y al cabo son.

Sin embargo, siguiendo a Burke, las imágenes exponen una riqueza visual que debe explorarse con mayor detenimiento en las reflexiones históricas. Como he afirmado en un párrafo anterior, por un lado ellas proyectan un reflejo perceptible de lo que el fotógrafo estaba viendo y, por otro, muestran una realidad material de las gentes y sus espacios. Esto es, como diría Burke ${ }^{9}$, un reflejo de la cultura material expresada en el punto de vista del observador y en lo que la imagen misma le muestra al mundo sobre los espacios explorados. Para los efectos de las fotografías compendiadas en Excursions et explorations dans la Colombie, Venezuela, Antilles, Etats-Units, Canadá, Tahití, se puede ver en la gran mayoría de ellas, un interés en el mundo tropical, el cual se manifiesta en la exuberancia no solo de lo vegetal, sino también en la exoticidad que varias imágenes del archivo fotográfico trabajado presentan, en general, de los habitantes del Gran Caribe.

Este trabajo centra su atención en recuperar las ilustraciones que dichas expediciones dejaron sobre la región del Caribe Colombiano tomando, como punto de referencia narrativa, los relatos de Wolfred Nelson acerca de los eventos del terremoto en ciudad de Panamá en 1882. Aunque Nelson no formó parte de las expediciones que se citan en este

8 Burke, Peter (2001): Eyewitnessing. The uses of images as historical evidence. London, Reaction Books Publishers.

9 Burke, Peter..Eyewitnessing...Op cit, Cap 5, pág. 81s. 
Revista Herencia, Vol. 34 (2), enero-junio, 2021.

trabajo, -al menos no hay constancia de su conexión-, su presencia durante los eventos sísmicos y, por ende, sus descripciones, son una pieza fundamental con la cual acompañar las imágenes que dejaron las expediciones antes mencionadas.

A pesar de que Nelson trabajó como corresponsal de un periódico extranjero, sus relatos de viaje no estuvieron acompañados de imágenes fotográficas, sino más bien de ilustraciones grabadas que bien podrían haber sido negativos fotográficos y esto tal vez se deba a que la publicación de sus relatos de viaje fue una empresa de intereses privados, una tarea que muchos le habían pedido llevar a cabo ${ }^{10}$; aun así resulta curioso que no presentara imágenes fotográficas de aquellos instantes, mientras su trabajo como corresponsal bien pudiera contener ilustraciones propias de una corresponsalía internacional, como fue su caso. Pero retorno con Nelson para reconstruir con sus impresiones lo que pasó aquella madrugada:

-Los momentos después del terremoto

Un Nelson atontado por las sacudidas que el evento telúrico había ejercido sobre su humanidad, narró como observador directo la experiencia vivida:

I shall never forget the scene in the plaza. It was black with people who had reached there in safety, and had got in the open and away from buildings that were expected to fall. There was still a little light, and the moon was in its last quarter. The hum of voices there and the excitement was something astonishing. There they were, people of all classes-black and white-some dressed, and some very hastily dressed, and some had brought chairs with them. An elderly lady belonging to one of the oldest and most distinguished of Colombian families was found dead sitting in her chair. It was an old case of heart disease, and it simply required the excitement to kill her. ${ }^{11}$

Tratar de describir lo que observaba en medio del bullicio y los temores de la gente que se agolpaba en la plaza a donde Nelson iría a parar buscando protegerse, quedó grabado en su memoria de forma indeleble:

10 Al respecto, véase el prefacio a Nelson, Wolfred (1889): Five years at Panamá...Op cit, Pagina xi.

11 Nunca olvidare la escena en la plaza. Estaba oscura con gente que había llegado allí a salvo y había salido a la luz y lejos de los edificios que se esperaba colapsaran. Había todavía un poco de luz y la luna estaba en su último cuarto. El murmullo de voces allí y la emoción fue algo asombroso. Había gente de todas las clases -negros y blancos- algunos vestidos, otros vestidos muy apresuradamente, y algunos habían traído asientos con ellos. Una anciana perteneciente a una de las más antiguas y más distinguidas familias colombianas fue encontrada sentada en su silla sin vida. Era un caso crónico de enfermedad cardíaca y simplemente era necesaria una emoción como esta para acabar con ella. Nelson, Wolfred (1889): Five years at Panama...Op cit, Página $171 \mathrm{~s}$ 
Revista Herencia, Vol. 34 (2), enero-junio, 2021.

With the return of daylight all seemed to recover some courage, for if there is anything that unnerves one, it is to feel the earth violently tremble under one, and hearing buildings groan. There was a vast deal of damage done in the city; walls had been thrown down, and there had been some accidents. A doctor of law in his fright had jumped from a balcony and broken his leg. In a house on the Calle Real a man and his wife had left their bed just as the upper wall of an adjoining building came through the ceiling, burying it under the debris. I should also say that at the Cathedral a number of the Saints had been shaken from their niches in its front. The old tower of the Chapel of Ease, opposite the Quinta of Santa Eita, had been shaken down, burying a wooden shanty from which the family had just escaped. The only fatality in the city of Panama was that of the old lady who died in the plaza ${ }^{12}$.

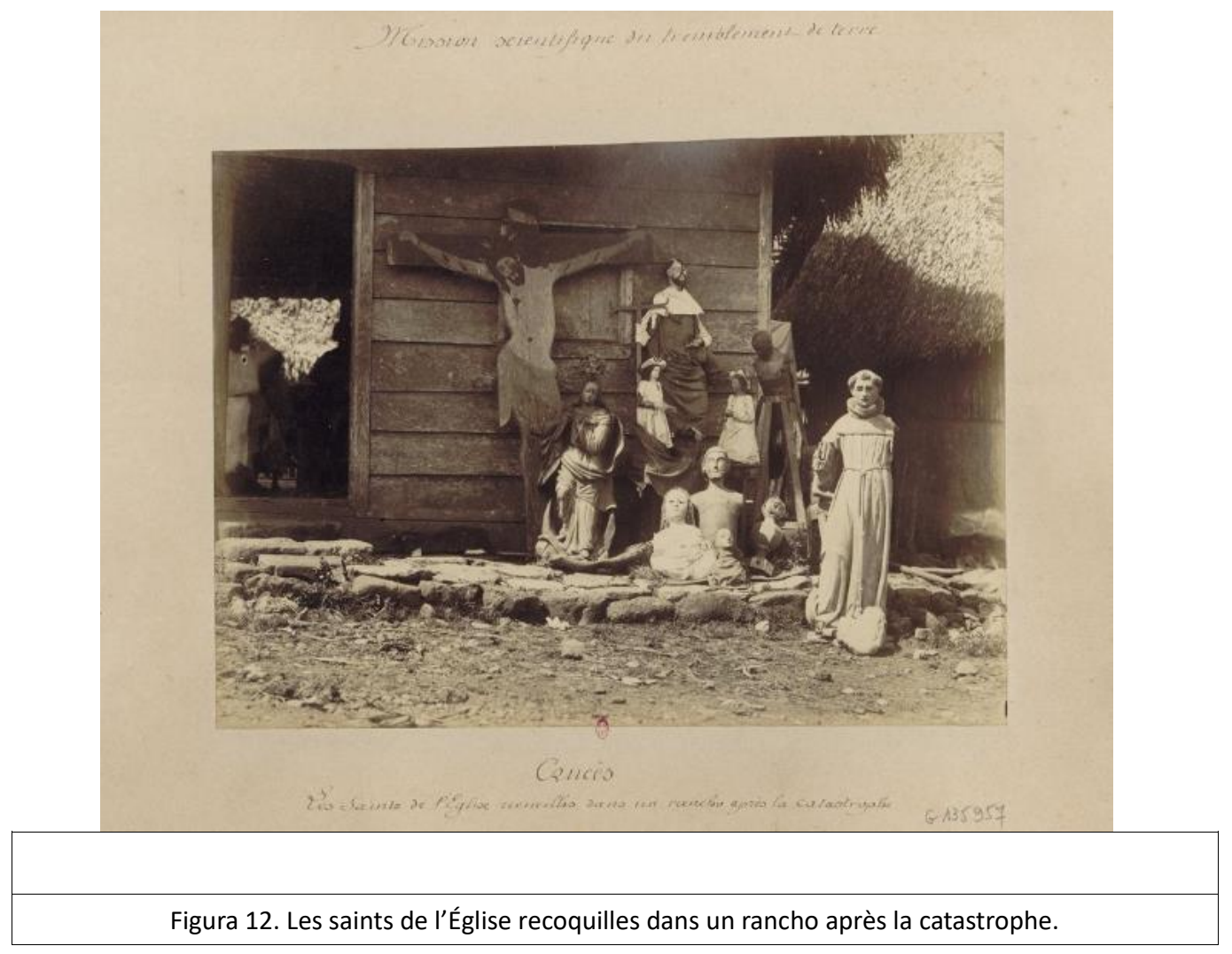

12 Con el retorno de la luz del día, todo pareció recobrar cierto ánimo, pero si hay algo desconcertante, es sentir que la tierra tiembla violentamente debajo de uno, y escuchar el gemido de los edificios. Hubo un gran daño en la ciudad; paredes que se cayeron, y hubo algunos accidentes. Un abogado, en medio del susto saltó desde el balcón y se rompió una pierna. En una casa de la Calle Real, un hombre y su mujer salieron de su cama justo cuando la pared superior del edificio de al lado cayó a través del techo, enterrándolo entre los escombros. Debería también anotar que en la Catedral, una parte de los Santos han sido sacudidos de sus nichos en la fachada. La torre antigua de la capilla, opuesta a la Quinta de Santa Eita, ha sido sacudida, enterrando un chanty de madera, del cual la familia apenas consiguió escapar. La única fatalidad en la ciudad de Panamá fue la de la anciana que murió en la plaza. Nelson, Wolfred (1889): Five years at Panamá...Op cit, Página 172. Nota: Aunque Nelson afirma que la única víctima fatal en ciudad de Panamá fue la señora de familia tradicional, las notas periodísticas de la época afirman lo contrario. 
Revista Herencia, Vol. 34 (2), enero-junio, 2021.

Y tal como lo expresó Nelson, la imagen encontrada en el compendio fotográfico de Excursions et explorations dans la Colombie, da cuenta de los relatos de forma visual de varios santos (figura 12), entre los que se pueden apreciar un cristo crucificado, una virgen, y varias otras estatuas y bustos (once en total), las cuales evidencian una iconografía que alguna vez hizo parte de una iglesia, en algún lugar del Panamá de entonces, los cuales fueron recuperados a la sazón de entre los escombros de iglesias que habrían colapsado enteramente:

Previous to the earthquake there had been a substantial stone church there. That building literally had been shaken to pieces. Its ruins were photographed by $M$. Demers, chief of the photographic service of the Panama Inter-oceanic Canal Company. Not a piece of the wall four feet high was standing. I learned subsequently that several lives had been lost in a small village between Colon and Panamá ${ }^{13}$.

Panamá quedó aislada de las comunicaciones con el resto del mundo. La fuerza con que el evento sacudió la región fue tal que no solo destruyó edificios, iglesias, los rieles del ferrocarril y algunos puentes, sino que, incluso, provocó un tsunami que arrasó el archipiélago de San Blas, generando una devastación sin precedentes en la historia del país. Además, el evento rompió el cable telegráfico que conectaba parte de Sur América, y que pasaba por Panamá hacia Centro América, México y los Estados Unidos, por lo que, de acuerdo con Nelson, solo pudo enviar un pequeño texto de 485 palabras, es decir, una página y media, informando de la situación al New York Herald ${ }^{14}$. Era tan escasa la información que circulaba, que solo hasta un mes más tarde se llegaron a saber datos de lo ocurrido en otras partes de la región.

13 Antes del terremoto había habido una importante iglesia de piedra allí. Esa edificación fue literalmente sacudida en pedazos. Sus ruinas fueron fotografiadas por el señor M. Demers, jefe del servicio de fotografía de la Compañía del Canal Interoceánico de Panamá. Ningún pedazo del muro de cuatro pies de altura se sostuvo en pie. Supe posteriormente que muchas vidas se perdieron en un pueblo pequeño entre Colón y Panamá. Nelson, Wolfred...Five years...Op cit, Página 174.

14 El New York Herald estuvo circulando en la ciudad de Nueva York desde su fundación en 1835 y hasta 1924. Se podría decir que fue el precursor de lo que hoy es el New York Times. Al respecto véase: https://www.britannica.com/topic/New-York-Herald 
Revista Herencia, Vol. 34 (2), enero-junio, 2021.
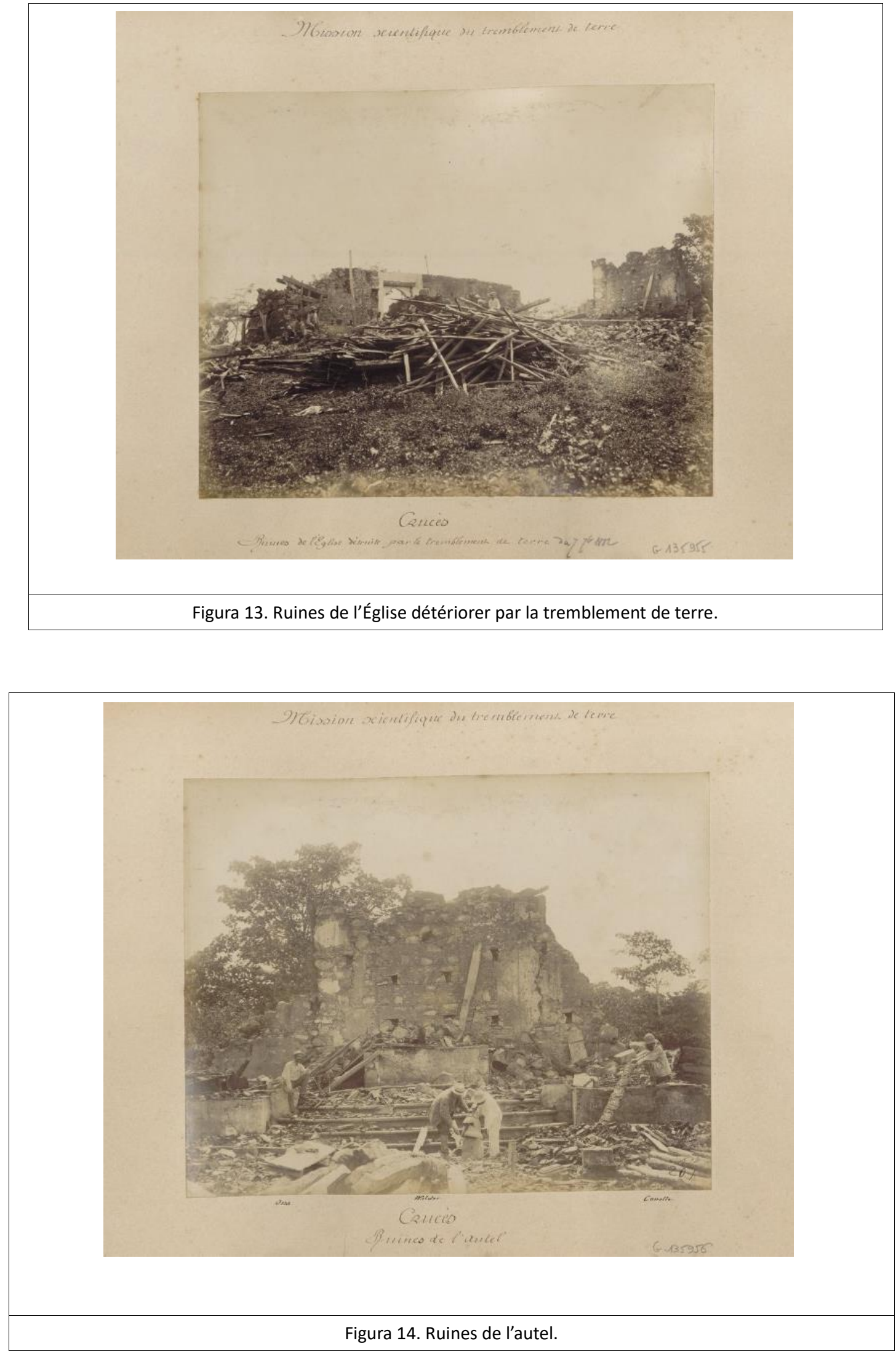
En muchas zonas cuyo elemento primordial de construcción seguía siendo la madera, las sacudidas habían dejado trozos del material esparcidos por todas partes (Figura 13 y 14).

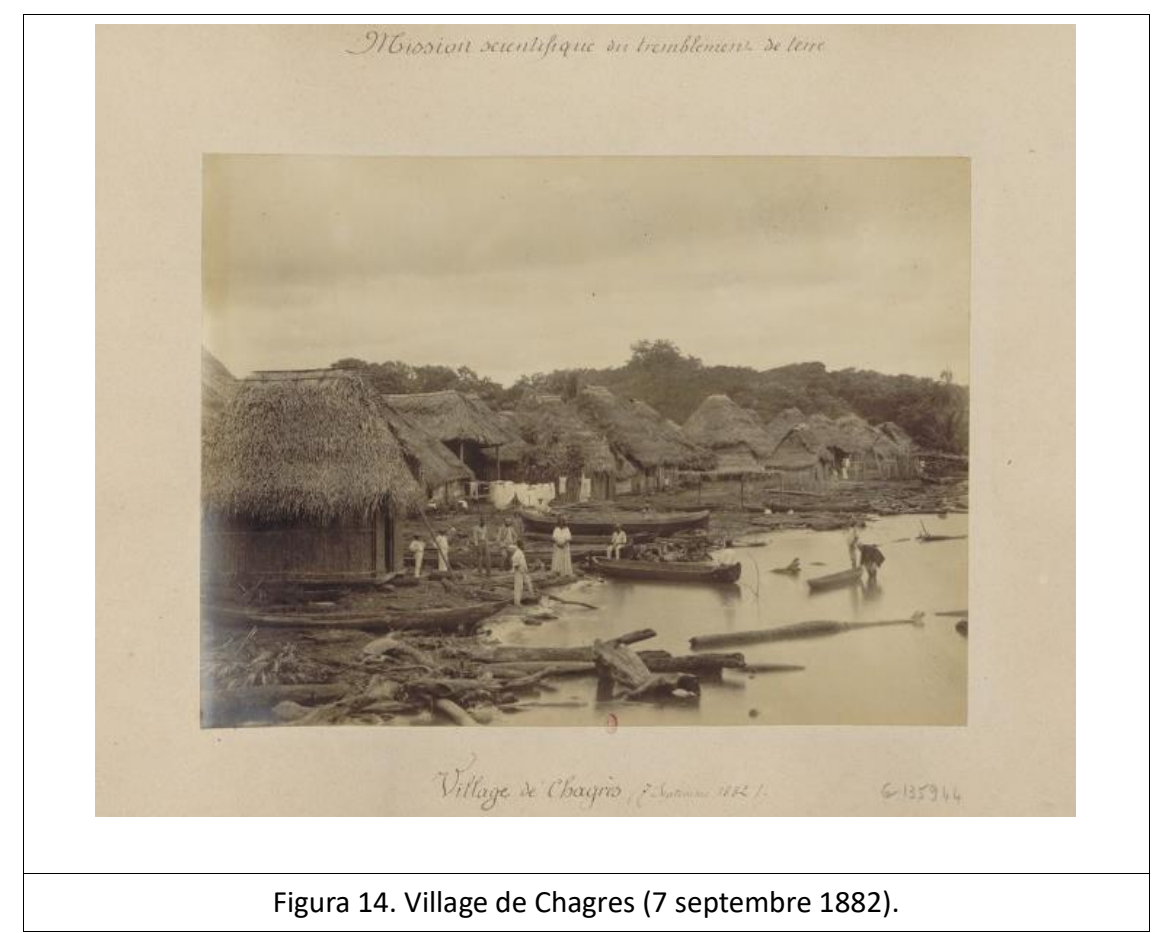

-Las ciudades del litoral Atlántico en la mirada fotográfica expedicionaria

En adición a las expediciones que se llevaron a cabo en varias zonas de la región de Panamá, entre 1882 y 1886, también se hicieron visitas a la parte continental más septentrional de lo que durante un periodo de 23 años (1863-1886) se llamó los Estados Unidos de Colombia. Los dos puertos principales del país, al margen de lo que se estaba cocinando en la zona del canal de Panamá, Cartagena y Barranquilla, ya tenían nombre propio, en un estado indudablemente gestionado de espaldas a la realidad de todo lo que no fuera el centro andino. Por tanto, estas ciudades operaban con cierta independencia, gracias a las distancias, y de paso a la dejadez de los gobernantes ubicados en Santa Fe de Bogotá; sin embargo, existía mucha relación entre ellas. 
Revista Herencia, Vol. 34 (2), enero-junio, 2021.

Varios viajeros atestiguan una conexión más estrecha entre estos puertos, al menos a nivel de las relaciones sociales ${ }^{15}$ y del contrabando de víveres a escalas aún no estudiadas, los cuales eran transportados en embarcaciones de mediana eslora que salían inicialmente de la zona de Chagres, y que, posteriormente, con la puesta en marcha del puerto de Aspinwall, permitió una mejoría en la comunicación, ya que a partir de entonces se salía directamente sin tener que serpentear el río Chagres, bordeando así toda la costa norte del istmo hasta llegar a los puertos de Cartagena, Barranquilla y Santa Marta. Eliseo Reclus, un viajero francés que estuvo en la zona del canal y que utilizó este servicio durante su recorrido por el Caribe Colombiano, narró así la experiencia de viajar en estas embarcaciones:

\begin{abstract}
La tripulación del Narciso se componía de cuatro hombres: el propietario, el capitán, el marinero y el grumete. El primero era un negro hercúleo, de fisonomía llena y placentera: acostado sobre el puente, miraba con satisfacción profunda las velas de su nave, infladas por el viento, los sacos de cacao amontonados en la bodega, y aun al humilde pasajero tendido a su lado; gozaba voluptuosamente el privilegio de poseer, y miraba con ternura las ondas sobre las cuales flotaba su goleta; entregado enteramente a su dicha, rara vez se dignaba ocuparse de la maniobra ni de prestar mano fuerte cuando se trataba de halar una cuerda o de virar de bordo. Por lo demás, era de una dulzura inefable, y deseaba ver a todos sus compañeros tan dichosos como él: si el capitán no hubiera mandado, si el marinero y el grumete se hubiera cruzado de brazos, se habría dejado estrellar apaciblemente contra un arrecife, sin que la satisfacción pintada en su fisonomía se hubiera turbado ${ }^{16}$.
\end{abstract}

De esta misma forma puede suponerse que viajaron los miembros de las expediciones que visitaron la zona del litoral atlántico, utilizando los servicios de dichas embarcaciones. La expedición que tuvo como destino las ciudades ubicadas en la mencionada zona, llevó por nombre Mission du Magdalena y tuvo lugar en enero de 1884:

15 Armand Reclus, hermano del famoso geógrafo Eliseo Reclus, quien visitó la zona del Canal de Panamá durante la segunda mitad del siglo XIX, en una de sus memorias sostuvo: Entre estas gentes solo un pasajero deseo o un capricho es lo que preside a las uniones de hombres con mujeres, así es que apenas si tienen duración, excepto en un limitado número de casos, y es bastante frecuente ver que una mujer con todos sus hijos pasa de la noche a la mañana desde la choza de un cartagenero a la de un panameño, sin que les llame en lo más mínimo la atención, ni sea entre ellos motivo de resentimiento o de disgustos. Las costumbres son estas, y por más raro que pueda ser, no las han reformado en el considerable número de años que llevan viviendo en aquellas regiones. En: Reclus, Armand (1881): Panamá et Darien. Voyages D’Exploration par Armand Reclus (1876-1878). Paris: Librairie Hachette et C., página 67.

16 Reclus, Eliseo (1869): Voyage a la Sierra-Nevada de Sainte-Marthe. Paysages de la nature tropicale. Paris: Librairie Hachette et C., Página 26s. 


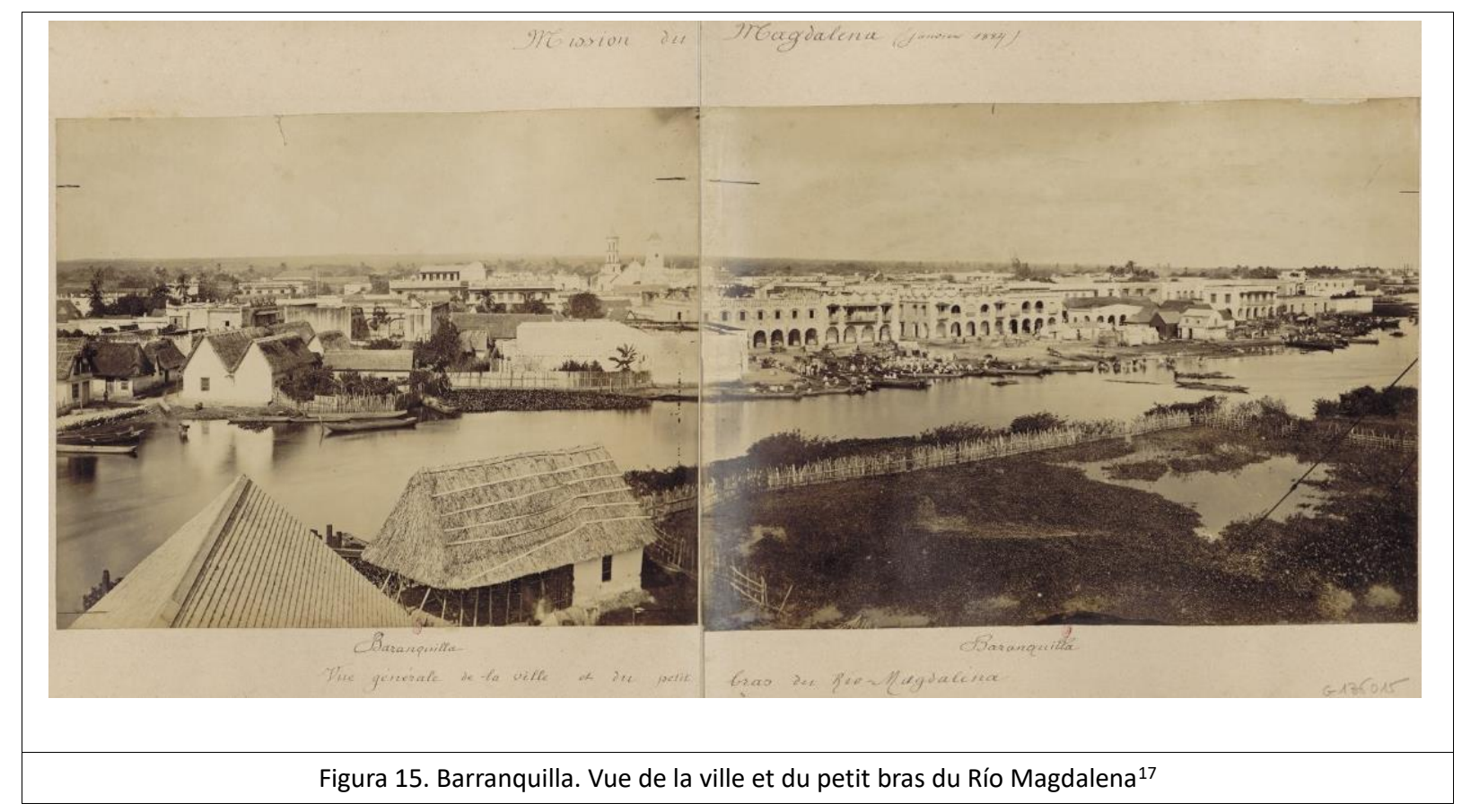

En la vista panorámica de Barranquilla (figura 15), se aprecia la intensa actividad de intercambio económico en la margen derecha del brazo, justo en frente de los edificios más republicanos. La ciudad le apostaba al comercio fluvial, el cual era el foco del crecimiento urbano. Más allá del desarrollo lineal, al margen del rio la ciudad crecía muy poco y dos o tres calles corrían paralelas al curso acuático, y cuya longitud no parecía ser muy extensa, como se puede apreciar. Wolfran Nelson, quien también visitó la ciudad en el lapso de los cinco años que vivió en Panamá, la describió de esta forma:

Barranquilla is an old town on the river Magdalena. The majority of the houses in the city are of stone covered by very thick thatches of native grasses resembling hay. These thatches are put on in the most substantial manner, and then are neatly squared off where they hang over the sidewalk. They are twelve to eighteen inches thick. These, with the whitewashed walls of the houses, present a somewhat peculiar appearance. Barranquilla is largely built on sandy soil. The streets are all sandy, travelling is most difficult, and the dust is constant ${ }^{18}$.

17 Barranquilla. Vista del poblado y del pequeño brazo del rio Magdalena. Nota: La imagen original se encuentra partida en dos en la página central del compendio, de ahí que presente cierta borrosidad en el centro de la misma.

18 Barranquilla es un viejo poblado en el rio Magdalena. La mayoría de las casas en la ciudad son de piedra y están cubiertas de paja muy gruesa, una especie de pasto parecido al heno. Esta paja es puesta de manera sustancial y luego es encuadrada perfectamente donde cuelgan sobre las aceras. Tienen entre doce y dieciocho pulgadas de ancho. Esto, junto a los muros encalados (blanqueados) de las casas, presenta una apariencia un tanto peculiar. Barranquilla está en gran parte construida en suelo arenoso. Las calles son todas arenosas. Viajar es más dificultoso y el polvo es constante. Nelson, Wolfred..Five years...Op cit, Página 184. 
Revista Herencia, Vol. 34 (2), enero-junio, 2021.

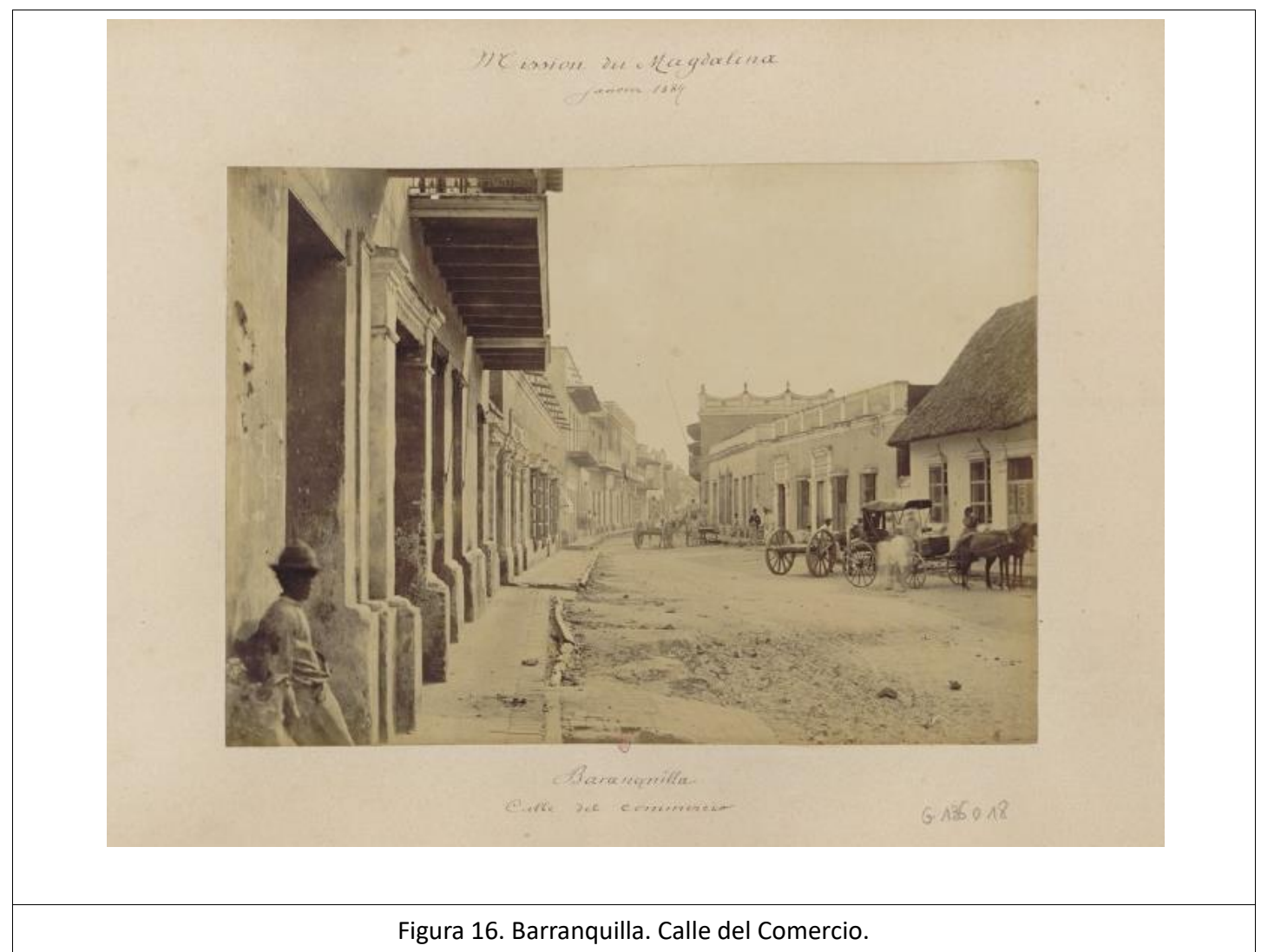

Calles sin pavimentar, y los edificios modernos cubiertos de polvo, fueron las impresiones captadas por los visitantes en la parte más desarrollada de la ciudad (figura 16), mientras en otra imagen una calle ancha contrasta con el tamaño de las casas (figura 17). 
Revista Herencia, Vol. 34 (2), enero-junio, 2021.

Revista Herencia, Vol. 34 (2), enero-junio, 2021.

Las calles arenosas, junto a las formas arquitectónicas y de construcción urbana fueron el foco de atención de los fotógrafos. Lo evidencian las imágenes antes mostradas, así como esa en la que se fotografía el pueblo de Calamar en una calle donde aparecen seis mujeres quienes han detenido su marcha para observar a quien las observa (figura 18). Los ranchos descritos por Nelson con techos cubiertos de paja aparecerán igualmente como elemento que reúne la atención tanto del viajero canadiense, como de los franceses, tanto en estas, como en las demás imágenes tomadas en otros asentamientos en la zona de Panamá.

Los medios de transporte también ocuparán un espacio dentro de las imágenes que componen el compendio de Excursions et explorations dans la Colombie, Venezuela, Antilles, Etats-Units, Canadá, Tahití. Al menos una veintena de ellas serán dedicadas a fotografiar las embarcaciones o los navíos utilizados por los locales para transportar mercancías y seres humanos.

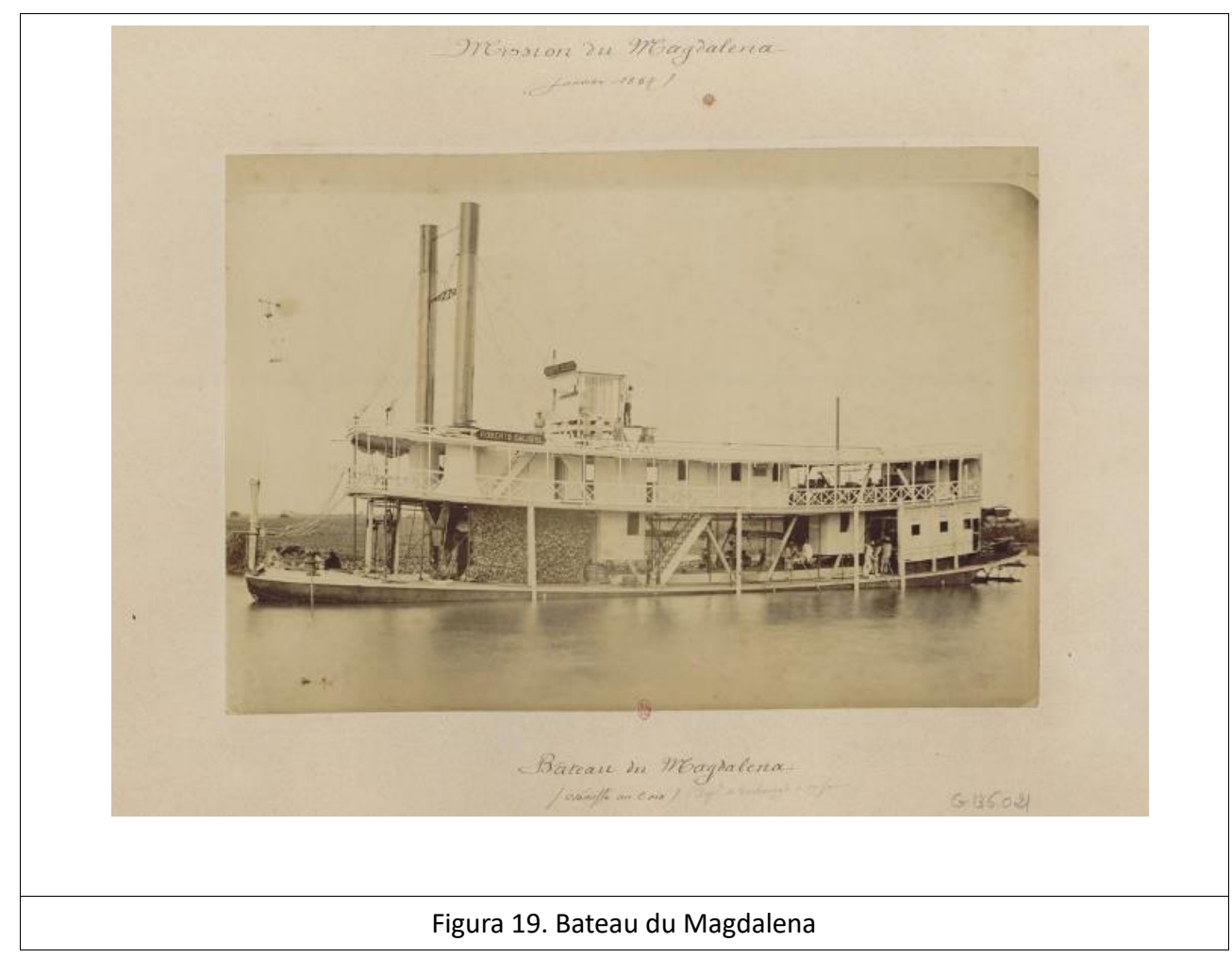


Revista Herencia, Vol. 34 (2), enero-junio, 2021.

Por su parte, de Cartagena y Santa Marta, los fotógrafos se detuvieron en recordar, de la primera, la zona del Cabrero, lugar de la casa del Presidente Núñez y, de la última, una vista panorámica de la bahía y de la ciudad junto a las montañas.

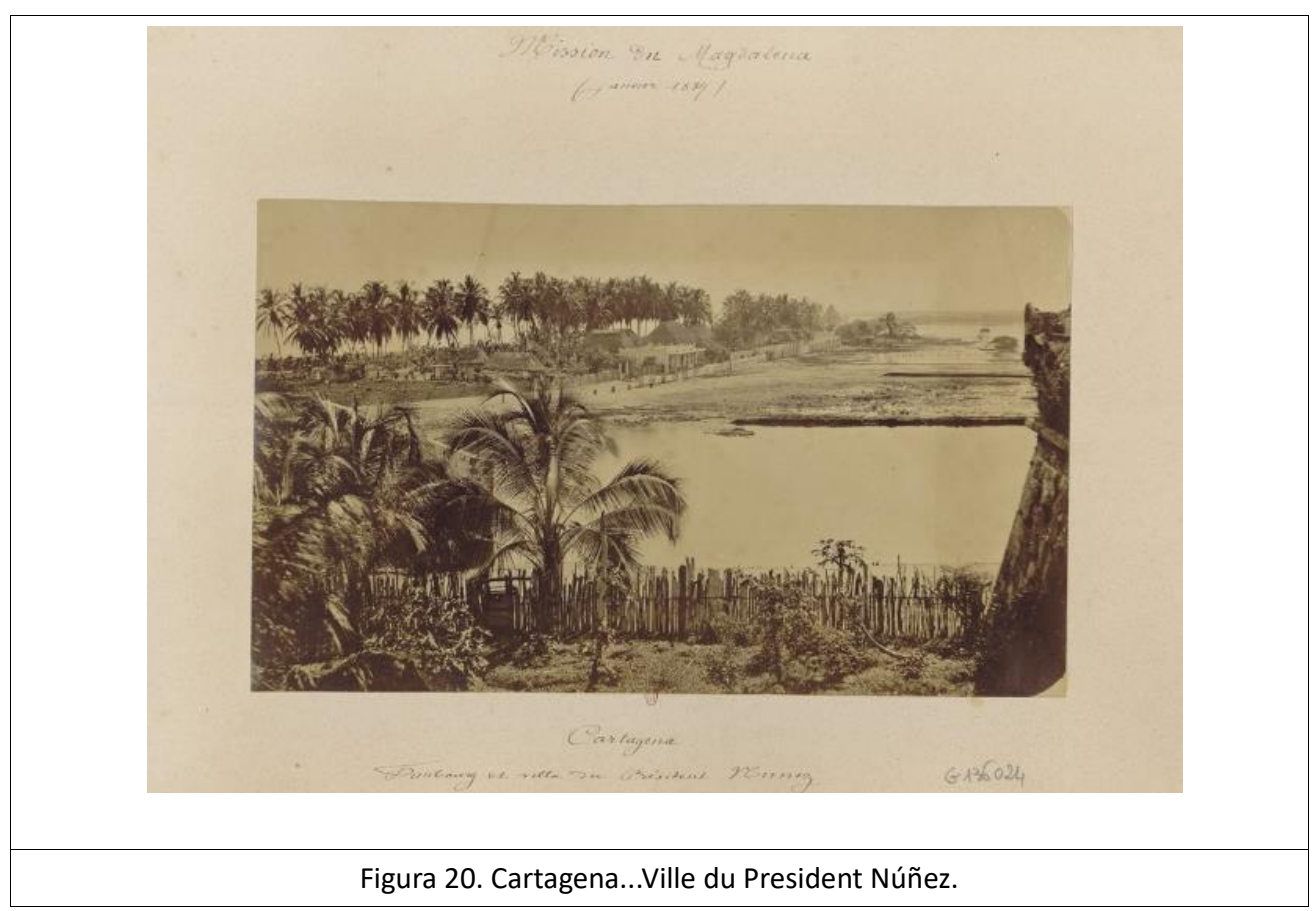


Revista Herencia, Vol. 34 (2), enero-junio, 2021.

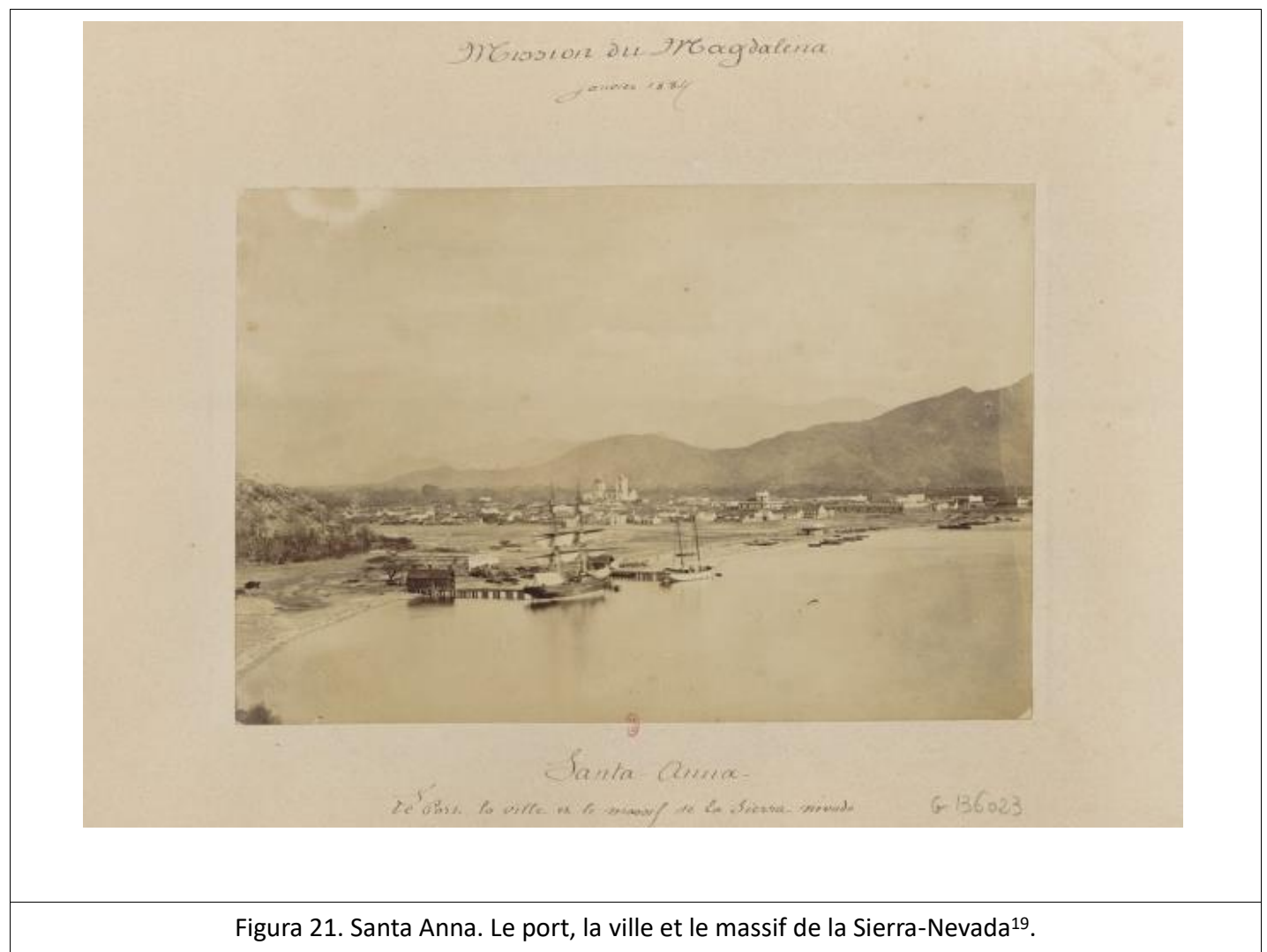

Conclusiones:

Como es lógico, algunas preguntas en relación con las expediciones que se realizaron en torno o al calor del terremoto de Panamá de 1882, quedan sin responder. ¿Por qué y para qué se llevaron a cabo dichas expediciones o misiones al interior del Caribe Colombiano de finales del siglo XIX? ¿Qué relación guardaban con aquellas que se llevaron a cabo en Estados Unidos, Canadá, Venezuela, las Antillas y Tahití? ¿Se trató, acaso, de un estudio sobre las fallas o quizás eventos telúricos en todos estos sitios? ¿Cuál fue el resultado de estos estudios? Quiénes eran los científicos que hacían parte de dichas misiones? ¿O tal vez estuviésemos, quizás, asistiendo a las primeras visitas turísticas a la región? La ausencia de

19 Aunque en la leyenda de esta imagen aparece el nombre como Santa Anna, realmente se trata de la ciudad de Santa Marta. El departamento del Magdalena tiene un pueblo llamado Santa Ana, pero este no se encuentra en la zona del litoral. 
Revista Herencia, Vol. 34 (2), enero-junio, 2021.

documentos que acompañen el compendio fotográfico trabajado, hacen que sea más problemático un análisis más completo de las expediciones.

Las imágenes tomadas en algunos sitios, de acuerdo con sus fechas, podrían indicar que ya estas misiones se estaban llevando a cabo y que algunos de los viajeros que las tomaron bien podrían haber sido igualmente testigos directos de los sucesos ocurridos durante los eventos sísmicos de 1882. Lo cierto es que la revisión de las imágenes encontradas en el compendio fotográfico arroja más preguntas sin responder que luces sobre las actividades llevadas a cabo entre 1882 y 1886.

La mirada fotográfica puede ser sesgada, teniendo en cuenta que solo enfoca aquello que despierta el interés del observador; aun así, más allá de las preguntas no resueltas, las representaciones de un mundo tropical, lleno de grandes riquezas acuíferas, vegetales y humanas, aportan un universo de información que bien vale la pena estudiar y que este ensayo exploratorio ha pretendido exponer dentro del marco de la historia regional del Caribe Colombiano. 
Revista Herencia, Vol. 34 (2), enero-junio, 2021.

\section{FUENTES:}

Guberman, Theodore, De Meuse, Robert et Cannelle. (1881-1887). Excursions et explorations dans la Colombie, Venezuela, Antilles, Etats-Units, Canaáa, Tahití. Paris: (n/a).

Nelson, Wolfred. (1889). Five years at Panamá. The trans-isthmian canal. New York: Belford Company Publishers.

Reclus, Armand. (1881). Panamá et Darien. Voyages D'Exploration par Armand Reclus (1876-1878). Paris: Librairie Hachette et C.

Reclus, Eliseo. (1869). Voyage a la Sierra-Nevada de Sainte-Marthe. Paysages de la nature tropicale. Paris: Librairie Hachette et C.,

\section{BIBLIOGRAFÍA:}

Araúz, C. y Pizzurno, P. (1993). El Panamá colombiano (1821-1903). Panamá: Editorial Chen. 
Revista Herencia, Vol. 34 (2), enero-junio, 2021.

Burke, Peter. (2001). Eyewitnessing. The uses of images as historical evidence. London: Reaction Books Publishers.

Jaén Suárez, Omar. (1973). Presencias imperialistas y dependencia ístmica en la segunda mitad del siglo XIX. Panamá: CISE-Universidad de Panamá.

Kerridge, Richard. (1999). Ecologies of desire; travel writing and nature writing as travelogue. In: Clark, Steve (ed) (1999): Travel writing and empire. London: Zed Books Publishers.

McCain, William. (1979). Los Estados Unidos y la República de Panamá. Panamá: Editorial Universitaria, Panamá.

Spurr, David. (2001). The rethoric of empire. Colonial discourse in journalism, travel writing and imperial administration. Durham: Duke University Press.

Stepan, Nancy Leys. (2001). Picturing tropical nature. London: Reaction Books Publishers.

Todorov, Tzvetan. (1991). Nosotros y los otros. Reflexión sobre la diversidad humana. México: Siglo XXI Ediciones.

Vega, Carmelo. (2011). Lógicas turísticas de la fotografía. Salamanca: Cátedra Ediciones. 
Revista Herencia, Vol. 34 (2), enero-junio, 2021. 